\title{
Positional distribution of fatty acids, and molecular species of polar lipids, in the diatom Phaeodactylum tricornutum
}

\author{
Wichien Yongmanitchai and OWen P. WaRD* \\ Department of Biology, University of Waterloo, Waterloo, Ontario, Canada N2L $3 G 1$
}

(Received 31 July 1992; revised 27 October 1992; accepted 6 November 1992)

\begin{abstract}
Each of the four main polar lipids from Phaeodactylum tricornutum UTEX 640, monogalactyosyldiacylglycerol (MGDG), digalactosyldiacylglycerol (DGDG), sulphoquinovosyldiacylglycerol (SQDG) and phosphatidylcholine (PC), was separated into its molecular species by reverse-phase HPLC, and the positional distribution of fatty acids in each species was determined. Numbers of separated peaks in each lipid class were: MGDG, 10; DGDG, 7; SQDG, 10; and PC, 11. Eicosapentaenoic acid (EPA) was present in 20 of the 45 molecular species but predominated in the MGDG and DGDG classes, where 13 of the proposed structures contained EPA. EPA was always located in the $s n-1$ position except in two lipid species, MG5 and PC2, where it was present at both the $s n-1$ and $s n-2$ locations. The predominant polar lipid molecular species found in $P$. tricornutum UTEX 640 were (mg total fatty acids per $\mathrm{g}$ dry weight of biomass) 20:5-16:4-MG, 41.2; 20:5-16:1-DG, 21.0; 16:1-16:1-SQ, 18.2; and 20:5-16:1-MG, 18.0. [Structure indicates fatty acid at $s n-1$ position - fatty acid at $s n-2$ position carbohydrate component at $s n-3$ position of the glycerol molecule. Abbreviations: 20:5, EPA; 16:4, hexadecatetraenoic acid; 16:1, palmitoleic acid; MG, monogalactose; DG, digalactose; SQ, sulphoquinovose.]
\end{abstract}

\section{Introduction}

Omega-3 fatty acids, eicosapentaenoic acid (EPA) and docosahexaenoic acid (DHA), are recognized as having beneficial effects in human health for prevention or treatment of a variety of diseases (Dyerberg et al., 1978). These polyunsaturated fatty acids have been shown to produce positive effects in three physiological areas, related to the heart and circulatory functions, inflammatory responses and cancer treatment. At a NATO Advanced Research Workshop (Simopoulos, 1989) the roles of EPA and DHA as anti-aggregatory, antithrombolytic and anti-inflammatory agents were confirmed, while in other areas it was concluded that promising observations required substantiation through further research.

While the major commercial source of these fatty acids is fish and fish oils, methods for their recovery from fish oils are complex and supply from fish is unlikely to meet future requirements. Hence alternative sources are being

\footnotetext{
*Author for correspondence. Tel: 519885 1211; fax 5197460614.

Abbreviations: MGDG, monogalactosyldiacylglycerol; DGDG, digalactosyldiacylglycerol; SQDG, sulphoquinovosylvdiacylglycerol; PC, phosphatidylcholine; DHA, docosahexaenoic acid (22:6); EPA, eicosapentaenoic acid (20:5); ECN, equivalent carbon number.
}

sought. Omega-3 fatty acids in fish oils are not synthesized de novo by the fish but rather originate in the marine micro-organisms upon which the fish feed. Consequently, algae, produced in efficient photobioreactors, or in open tanks or ponds, are being considered as sources of purified omega-3 fatty acids or as a biomass feed for use in mariculture. We have previously described factors affecting production of EPA by the diatom Phaeodactylum tricornutum (Yongmanitchai \& Ward, 1991a). This alga has been found to produce up to $133 \mathrm{mg} \mathrm{EPA} \mathrm{m}^{-1}$ in batch culture, which amounted to $28 \%$ of total fatty acids produced. A simple silica gel cartridge method was used to separate the polar and non-polar lipids extracted from $P$. tricornutum, with four main polar lipids being isolated. Approximately $90 \%$ of the total EPA produced by $P$. tricornutum was associated with the polar lipid fraction (Yongmanitchai \& Ward, 1992).

We have now separated the molecular species present in each of the main polar lipid fractions, characterized the fatty acid components in each species and determined their positional distribution in the lipid molecule.

\section{Methods}

Organism. Phaeodactylum tricornutum UTEX 640 was obtained from the Culture Collection of Algae at the University of Texas at Austin, USA. 


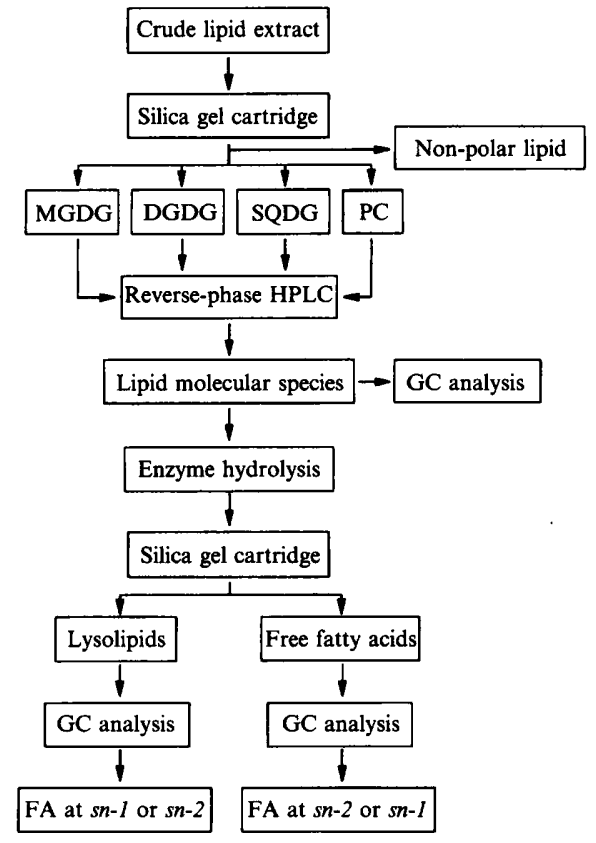

Fig. 1. Schematic diagram of lipid characterization.

Culture conditions. The diatom was cultivated under conditions described previously (Yongmanitchai \& Ward, 1991 a).

Reagents. All solvents and chemicals used were either analytical or HPLC grade and were obtained from Fisher and Caledon. Lipid and fatty acid standards, lipase from Rhizopus arrhizus and phospholipase $\mathrm{A}_{2}$ from Crotalus arox venom were purchased from Sigma.

Lipid extraction. A modification of the method of Bligh \& Dyer (1959) was used.

Preliminary fractionation of lipid by silica gel cartridge. For preliminary separation of lipid into non-polar and polar lipid classes, each fraction was eluted successively from a disposable silica cartridge by different organic solvent systems with increasing polarity, as described previously (Yongmanitchai \& Ward, 1992).

Molecular species separation of lipids by HPLC. Lipid molecular species were analysed by using an HPLC (Waters, Millipore Corporation) consisting of an auto-injector WISP 712, a multisolvent delivery system $600 \mathrm{E}$, an absorbance detector 484 , a differential refractometer R401 and an integrator data module 745 . A fraction collector (Retriever IV, ISCO) was connected to the detector outlet for collection of each individual peak for further analyses. Analysis conditions for separation of each individual lipid class were as follows.

Molecular species of galactolipids, including monogalactyosyldiacylglycerol (MGDG), digalactosyldiacylglycerol (DGDG) and sulphoquinovosyldiacylglycerol (SQDG), were separated by reverse-phase HPLC, using Spherisorb ODS II $5 \mu \mathrm{m}(4.6 \times 150 \mathrm{~mm})$ and a UV detector at $202 \mathrm{~nm}$ (Yamauchi et al., 1982). The same solvent system, methanol/water $(90: 10, \mathrm{v} / \mathrm{v})$ was employed for the three lipids; a flow rate of $1.0 \mathrm{ml} \mathrm{min}^{-1}$ was used for MDGD and $1.5 \mathrm{ml} \mathrm{min}^{-1}$ for DGDG and SQDG.

The phosphatidylcholine (PC) fraction was pre-purified using normal-phase HPLC on Zorbax Sil $5 \mu \mathrm{m}(4.6 \times 250 \mathrm{~mm})$ eluted with acetonitrile/methanol/water $(50: 45: 6 \cdot 5$, by vol.) at a flow rate of $0.4 \mathrm{ml} \mathrm{min}^{-1}$ (Kaitaranta \& Bessman, 1981). The purified phospholipid was then separated into molecular species by reverse-phase HPLC using Spherisorb ODS II $5 \mu \mathrm{m}(4.6 \times 150 \mathrm{~mm})$ and a UV detector at $205 \mathrm{~nm}$. The mobile phase was methanol/water/acetonitrile

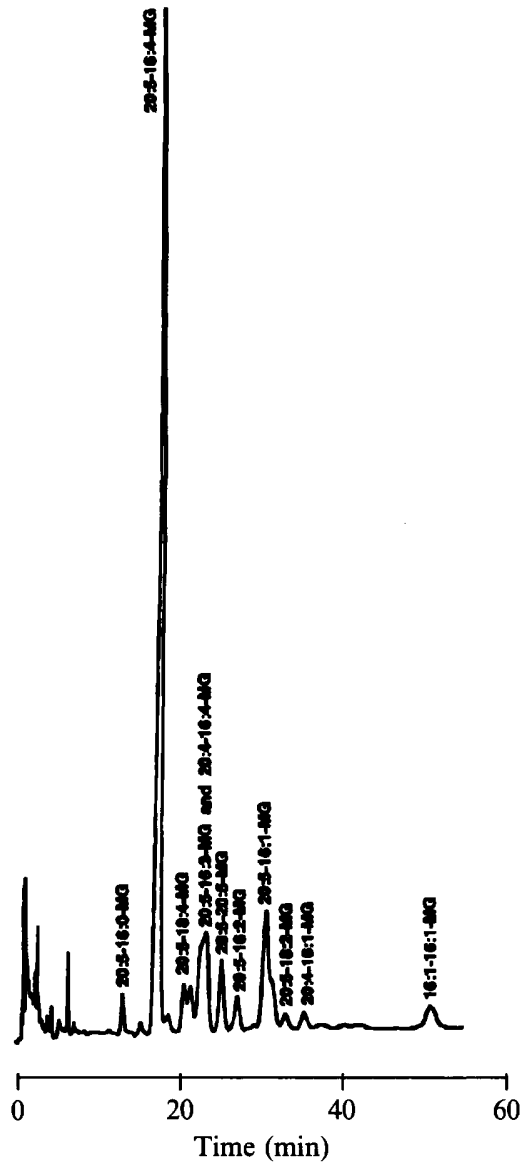

Fig. 2. Separation of MGDG molecular species from P. tricornutum UTEX 640 by reverse-phase HPLC on a Spherisorb ODS, $5 \mu \mathrm{m}$ column $(4.6 \times 150 \mathrm{~mm})$ eluted with methanol/water $(90: 10, \mathrm{v} / \mathrm{v})$ at a flow rate of $1.0 \mathrm{ml} \mathrm{min}^{-1}$, with UV detection at $202 \mathrm{~nm}$. Peaks were numbered MG1 to MG10 from left to right (see text and Tables 1 and 2).

( $90 \cdot 5: 7: 2 \cdot 5$, by vol.) containing $20 \mathrm{~mm}$-choline chloride; the flow rate was $1.0 \mathrm{ml} \mathrm{min}^{-1}$ for $25 \mathrm{~min}$ and was then increased to $1.5 \mathrm{ml} \mathrm{min}-1$ for $15 \mathrm{~min}$.

Determination of positional distribution of fatty acids. The positional distribution of fatty acids in galactolipids was determined by enzyme hydrolysis of sn-I fatty acids using lipase from Rhizopus arrhizus (Fischer et al., 1973). Hydrolysis of fatty acids at the $s n-2$ position of PC was carried out by phospholipase $\mathrm{A}_{2}$ as described by Watanabe et al. (1980). After incubation, the hydrolysate was extracted twice with chloroform/methanol $(2: 1, \mathrm{v} / \mathrm{v})$. The chloroform layer was collected and dried under nitrogen. The hydrolysates were redissolved in hexane/diethyl ether $(1: 1, \mathrm{v} / \mathrm{v})$ and loaded into a silica cartridge (SepPak, Waters). Free fatty acids were eluted from the column by $15 \mathrm{ml}$ hexane/diethyl ether $(1: 1)$. The remaining lysolipids were washed out with $15 \mathrm{ml}$ methanol. Each fraction was collected and its fatty acid constituents determined by gas chromatography after transmethylation.

Fatty acid analysis. Lipid and fatty acid samples were transmethylated using the acid methanolysis procedure of Holub \& Skeaff (1987) and injected into a gas chromatograph, Shimadzu model GC-14A, equipped with flame ionization detector and data integrator model $\mathrm{C}$ - 
Table 1. Fatty acid distribution in the MGDG fraction

\begin{tabular}{|c|c|c|c|c|c|c|c|c|c|c|c|}
\hline \multirow[b]{2}{*}{ Peak } & \multirow{2}{*}{$\begin{array}{c}\text { Galactose } \\
(\mu \mathrm{mol})\end{array}$} & \multicolumn{10}{|c|}{ Fatty acid content $(\mu \mathrm{mol})^{*}$} \\
\hline & & $16: 0$ & $16: 1$ & $16: 2$ & $16: 3$ & $16: 4$ & $18: 1$ & $18: 2$ & $20: 4$ & $20: 5$ & $22: 6$ \\
\hline MGl & $6 \cdot 1$ & $10 \cdot 7$ & $2 \cdot 4$ & & & & $5 \cdot 8$ & 0.8 & 0.9 & $14 \cdot 2$ & \\
\hline MG2 & 176.8 & $4 \cdot 1$ & 4.8 & & 1.6 & 189.1 & 1.7 & & 0.7 & 149.7 & \\
\hline MG3† & $10 \cdot 5$ & 1.6 & $1 \cdot 3$ & & & 1.6 & & & & $7 \cdot 7$ & \\
\hline MG4 & $75 \cdot 9$ & $1 \cdot 3$ & $2 \cdot 4$ & $1 \cdot 6$ & 18.7 & 16.9 & 0.9 & & $17 \cdot 2$ & 19.2 & \\
\hline MG5 & $17 \cdot 8$ & & 1.0 & $0 \cdot 1$ & $0 \cdot 1$ & 0.2 & & & $1 \cdot 3$ & 25.0 & \\
\hline MG6 & $17 \cdot 2$ & 0.7 & 4.0 & 9.0 & & $0 \cdot 1$ & & & 0.9 & $10 \cdot 5$ & \\
\hline MG7 & $62 \cdot 2$ & $1 \cdot 3$ & 67.0 & 8.8 & $6 \cdot 6$ & $1 \cdot 3$ & 1.9 & & $5 \cdot 1$ & $81 \cdot 4$ & $10 \cdot 8$ \\
\hline MG8 & $11 \cdot 7$ & $1 \cdot 7$ & $2 \cdot 2$ & $0 \cdot 6$ & & & $1 \cdot 1$ & 13.9 & & $17 \cdot 2$ & \\
\hline MG9 & $19 \cdot 2$ & 1.5 & 7.9 & & & & 0.7 & $1 \cdot 1$ & $4 \cdot 3$ & $1 \cdot 3$ & \\
\hline MG10 & $22 \cdot 8$ & $2 \cdot 2$ & 49.8 & & & & 0.8 & $2 \cdot 2$ & 5.0 & 5.9 & 0.7 \\
\hline
\end{tabular}

* In this and the other tables, major values are shown in bold italic type. Minor amounts of 18:0 and 18:3 were detected in some peaks of the MGDG fraction.

$\dagger$ This peak contained an unidentified fatty acid which appeared to be $18: 4$.

Table 2. Positional distribution of major fatty acids in molecular species of lipids in the MGDG fraction

\begin{tabular}{|c|c|c|c|c|c|c|c|c|c|c|c|c|}
\hline \multirow[b]{2}{*}{ Peak } & \multirow[b]{2}{*}{ Posn } & \multicolumn{9}{|c|}{ Fatty acid content $(\mu \mathrm{mol})$} & \multirow{2}{*}{$\begin{array}{l}\text { Possible } \\
\text { MGDG }\end{array}$} & \multirow[b]{2}{*}{$\mathrm{ECN}$} \\
\hline & & $16: 0$ & $16: 1$ & $16: 2$ & $16: 3$ & $16: 4$ & $18: 1$ & $18: 2$ & $20: 4$ & $20: 5$ & & \\
\hline MG1 & $\begin{array}{l}s n-1 \\
s n-2\end{array}$ & $\begin{array}{l}0.5 \\
7 \cdot 1\end{array}$ & $\begin{array}{l}0.6 \\
1.0\end{array}$ & & & & & $\begin{array}{l}5 \cdot 7 \\
0 \cdot 4\end{array}$ & & $\begin{array}{l}8.6 \\
1.0\end{array}$ & $20: 5-16: 0-M G$ & 26 \\
\hline MG2 & $\begin{array}{l}s n-1 \\
s n-2\end{array}$ & $\begin{array}{l}1 \cdot 1 \\
2 \cdot 5\end{array}$ & $\begin{array}{l}4 \cdot 9 \\
1 \cdot 2\end{array}$ & & 0.8 & $\begin{array}{r}0.4 \\
107.5\end{array}$ & & $1 \cdot 1$ & & $\begin{array}{r}94 \cdot 0 \\
5 \cdot 2\end{array}$ & $20: 5-16: 4-M G$ & 18 \\
\hline MG3 & $\begin{array}{l}s n-1 \\
s n-2\end{array}$ & $\begin{array}{l}1 \cdot 0 \\
0.8\end{array}$ & $\begin{array}{l}0 \cdot 6 \\
2 \cdot 1\end{array}$ & & & $\begin{array}{l}0 \cdot 4 \\
1 \cdot 2\end{array}$ & & & & $\begin{array}{l}5 \cdot 2 \\
0 \cdot 5\end{array}$ & $20: 5-18: 4-M G$ & 20 \\
\hline MG4 & $\begin{array}{l}s n-1 \\
s n-2\end{array}$ & $\begin{array}{l}0.8 \\
0.8\end{array}$ & $\begin{array}{l}0.9 \\
1.2\end{array}$ & $\begin{array}{l}0 \cdot 4 \\
0 \cdot 8\end{array}$ & $\begin{array}{r}0.8 \\
14.8\end{array}$ & $\begin{array}{r}0 \cdot 4 \\
11 \cdot 3\end{array}$ & $\begin{array}{l}0 \cdot 6 \\
0 \cdot 4\end{array}$ & & $\begin{array}{l}9.0 \\
0.5\end{array}$ & $\begin{array}{r}16 \cdot 2 \\
2 \cdot 1\end{array}$ & $\begin{array}{l}20: 5-16: 3-M G ~ \& ~ \\
20: 4-16: 4-M G\end{array}$ & 20 \\
\hline MG5 & $\begin{array}{l}s n-1 \\
s n-2\end{array}$ & 0.8 & $\begin{array}{l}1 \cdot 3 \\
0 \cdot 9\end{array}$ & & & $\begin{array}{l}1.2 \\
0.8\end{array}$ & & & 0.4 & $\begin{array}{l}9.5 \\
7.6\end{array}$ & $20: 5-20: 5-M G$ & 20 \\
\hline MG6 & $\begin{array}{l}s n-1 \\
s n-2\end{array}$ & $\begin{array}{l}0 \cdot 6 \\
0 \cdot 4\end{array}$ & $1 \cdot 0$ & $\begin{array}{l}0.4 \\
7.5\end{array}$ & & & 0.5 & 0.2 & $0 \cdot 3$ & $\begin{array}{l}5 \cdot 6 \\
2 \cdot 2\end{array}$ & $20: 5-16: 2-M G$ & 22 \\
\hline MG7 & $\begin{array}{l}s n-1 \\
s n-2\end{array}$ & $0 \cdot 6$ & $\begin{array}{r}2 \cdot 2 \\
21 \cdot 0\end{array}$ & 0.4 & $\begin{array}{l}0.8 \\
1 \cdot 2\end{array}$ & $1 \cdot 2$ & 0.4 & & $\begin{array}{l}0.8 \\
0.7\end{array}$ & $\begin{array}{r}20.0 \\
2.7\end{array}$ & $20: 5-16: 1-M G$ & 24 \\
\hline MG8 & $\begin{array}{l}s n-1 \\
s n-2\end{array}$ & $\begin{array}{l}0.8 \\
0.4\end{array}$ & $\begin{array}{l}0 \cdot 4 \\
1 \cdot 2\end{array}$ & & & & 0.4 & $\begin{array}{l}0 \cdot 4 \\
5 \cdot 0\end{array}$ & & $\begin{array}{l}7.9 \\
1.3\end{array}$ & $20: 5-18: 2-M G$ & 24 \\
\hline MG9 & $\begin{array}{l}s n-1 \\
s n-2\end{array}$ & $\begin{array}{l}0.4 \\
0.5\end{array}$ & $\begin{array}{l}0.6 \\
3.9\end{array}$ & & & & $\begin{array}{l}1 \cdot 0 \\
0 \cdot 2\end{array}$ & 0.5 & $\begin{array}{l}5 \cdot 6 \\
0 \cdot 8\end{array}$ & $\begin{array}{l}1 \cdot 3 \\
0.5\end{array}$ & $20: 4-16: 1-M G$ & 26 \\
\hline MG10 & $\begin{array}{l}s n-1 \\
s n-2\end{array}$ & $\begin{array}{l}0 \cdot 3 \\
0.5\end{array}$ & $\begin{array}{l}16 \cdot 5 \\
15 \cdot 1\end{array}$ & & & & & $\begin{array}{l}0 \cdot 2 \\
0 \cdot 2\end{array}$ & $\begin{array}{l}0 \cdot 5 \\
0 \cdot 3\end{array}$ & $\begin{array}{l}2 \cdot 2 \\
1 \cdot 4\end{array}$ & $16: 1-16: 1-M G$ & 30 \\
\hline
\end{tabular}

R6A, as previously described (Yongmanitchai \& Ward, 1991b). As fatty acid standards of 16:2, 16:3 and 16:4 were not commercially available, the equivalent chain length (ECL) technique (Christie, 1987, 1988; Miwa et al., 1960) was used for identification of these fatty acids.

For determination of specific sugars in lipid fractions, glycosylglycerol lipids were hydrolyzed according to a modification of the method of Holub \& Skeaff (1987). Lipid fractions in chloroform were placed in $15 \mathrm{ml}$ screw-capped test tubes and dried at $40{ }^{\circ} \mathrm{C}$ under a stream of nitrogen. Distilled water $(0.5 \mathrm{ml})$ and $2 \mathrm{ml}$ acidified methanol $\left(6 \%, v / v, \mathrm{H}_{2} \mathrm{SO}_{4}\right.$ in methanol) were added. The solution was vigorously vortex-mixed for $2 \mathrm{~min}$, then the screw cap was tightened. Tubes were incubated at $80^{\circ} \mathrm{C}$ for $12 \mathrm{~h}$ to achieve hydrolysis and the aqueous methanolic phase was then neutralized with $1 \mathrm{M}-\mathrm{NaOH}$. The hydro- lysate was extracted twice with chloroform $(2 \mathrm{ml})$ to remove free fatty acid, and the remaining aqueous methanolic hydrolysate was dried under vacuum at $50^{\circ} \mathrm{C}$ and redissolved in $1 \mathrm{ml}$ distilled water for galactose determination.

Determination of galactose. Galactose was determined enzymically using a lactose/D-galactose kit (Boehringer Mannheim).

\section{Results and Discussion}

Each of the four polar lipids, MGDG, DGDG, SQDG and $\mathrm{PC}$, separated on a silica gel cartridge, was then separated into its molecular species by reverse-phase 
Table 3. Fatty acid distribution in the DGDG fraction

\begin{tabular}{lcccccccr}
\hline \hline & & \multicolumn{7}{c}{ Fatty acid content $(\mu \mathrm{mol})^{*}$} \\
\cline { 2 - 9 } Palactose & $(\mu \mathrm{mol})$ & $16: 0$ & $16: 1$ & $16: 3$ & $16: 4$ & $18: 1$ & $18: 2$ & $20: 5$ \\
\hline DG1 & 5.8 & 0.5 & 0.6 & & $\mathbf{1 . 9}$ & 0.4 & & $\mathbf{1 . 6}$ \\
DG2 & 40.5 & 1.9 & 2.4 & $\mathbf{1 3 . 9}$ & 0.4 & 1.0 & 1.1 & $\mathbf{1 8 . 7}$ \\
DG3 & 10.5 & $2 \cdot 1$ & 0.6 & $\mathbf{4 . 6}$ & & $\mathbf{5 . 2}$ & $\mathbf{4 . 4}$ & $\mathbf{4 . 0}$ \\
DG4 & 100.5 & 4.1 & $\mathbf{5 1 . 6}$ & $\mathbf{0 . 4}$ & 0.8 & 1.2 & 1.5 & $\mathbf{5 5 . 7}$ \\
DG5 & 68.3 & 2.7 & $\mathbf{3 4 . 8}$ & 0.4 & & 1.7 & 0.8 & 7.6 \\
DG6 & 6.8 & 0.8 & $\mathbf{4 . 3}$ & & & $\mathbf{3 . 2}$ & 0.4 & 1.3 \\
DG7 & 45.5 & $\mathbf{1 1 . 7}$ & 0.4 & & 0.8 & 0.7 & 0.8 & $\mathbf{1 2 . 8}$ \\
\hline \hline
\end{tabular}

* Minor amounts of 18:0,18:3 and 20:4 were detected in some peaks.

Table 4. Positional distribution of major fatty acids in molecular species of lipids in the DGDG fraction

\begin{tabular}{|c|c|c|c|c|c|c|c|c|c|c|}
\hline \multirow[b]{2}{*}{ Peak } & \multirow[b]{2}{*}{ Posn } & \multicolumn{7}{|c|}{ Fatty acid content $(\mu \mathrm{mol})^{*}$} & \multirow{2}{*}{$\begin{array}{l}\text { Possible } \\
\text { DGDG }\end{array}$} & \multirow[b]{2}{*}{$\mathrm{ECN}$} \\
\hline & & $16: 0$ & $16: 1$ & $16: 3$ & $16: 4$ & $18: 1$ & $18: 2$ & $20: 5$ & & \\
\hline DG1 & $\begin{array}{l}s n-1 \\
s n-2\end{array}$ & $\begin{array}{l}0 \cdot 2 \\
0 \cdot 5\end{array}$ & $\begin{array}{l}0.2 \\
0.4\end{array}$ & & $\begin{array}{l}0 \cdot 4 \\
2 \cdot 1\end{array}$ & $\begin{array}{l}0 \cdot 4 \\
0 \cdot 3\end{array}$ & $\begin{array}{l}0 \cdot 4 \\
0 \cdot 4\end{array}$ & $\begin{array}{l}2 \cdot 2 \\
0.5\end{array}$ & $20: 5-16: 4-D G$ & 16 \\
\hline DG2 & $\begin{array}{l}s n-1 \\
s n-2\end{array}$ & $\begin{array}{l}1 \cdot 8 \\
1 \cdot 3\end{array}$ & $\begin{array}{l}1 \cdot 7 \\
1 \cdot 0\end{array}$ & $\begin{array}{l}1 \cdot 0 \\
6 \cdot 8\end{array}$ & & $\begin{array}{l}1 \cdot 3 \\
0 \cdot 5\end{array}$ & $1 \cdot 0$ & $\begin{array}{l}8 \cdot 2 \\
1 \cdot 0\end{array}$ & $20: 5-16: 3-D G$ & 20 \\
\hline DG3 & $\begin{array}{l}s n-1 \\
s n-2\end{array}$ & $\begin{array}{l}0 \cdot 2 \\
1 \cdot 0\end{array}$ & $\begin{array}{l}0.7 \\
0.7\end{array}$ & $\begin{array}{l}0 \cdot 9 \\
3 \cdot 1\end{array}$ & & $\begin{array}{l}3 \cdot 2 \\
0.5\end{array}$ & $\begin{array}{l}0 \cdot 8 \\
4 \cdot 7\end{array}$ & 3.6 & $\begin{array}{l}20: 5-18 \cdot 2-X \quad \& \\
18 \cdot 1-16 \cdot 3-X\end{array}$ & 24 \\
\hline DG4 & $\begin{array}{l}s n-1 \\
s n-2\end{array}$ & $\begin{array}{l}1 \cdot 4 \\
1 \cdot 8\end{array}$ & $\begin{array}{r}1 \cdot 0 \\
25 \cdot 7\end{array}$ & $\begin{array}{l}0 \cdot 4 \\
0 \cdot 4\end{array}$ & $\begin{array}{l}0 \cdot 8 \\
0.4\end{array}$ & $\begin{array}{l}1 \cdot 0 \\
0.5\end{array}$ & $1 \cdot 1$ & $\begin{array}{r}26 \cdot 8 \\
1.7\end{array}$ & $20: 5-16: 1-D G$ & 24 \\
\hline DG5 & $\begin{array}{l}s n-1 \\
s n-2\end{array}$ & $\begin{array}{l}1 \cdot 2 \\
1.0\end{array}$ & $\begin{array}{r}10 \cdot 2 \\
8 \cdot 2\end{array}$ & 0.8 & & $1 \cdot 3$ & $\begin{array}{l}0.9 \\
1 \cdot 4\end{array}$ & $\begin{array}{l}0 \cdot 4 \\
0 \cdot 4\end{array}$ & $16: 1-16: 1-\mathrm{DG}$ & 30 \\
\hline DG6 & $\begin{array}{l}s n-1 \\
s n-2\end{array}$ & $\begin{array}{l}0.8 \\
0.4\end{array}$ & $\begin{array}{l}1 \cdot 2 \\
2 \cdot 4\end{array}$ & & & $\begin{array}{l}2 \cdot 1 \\
0.7\end{array}$ & & 0.7 & $18: 1-16: 1-D G$ & 30 \\
\hline DG7 & $\begin{array}{l}s n-1 \\
s n-2\end{array}$ & $\begin{array}{l}1 \cdot 4 \\
4 \cdot 1\end{array}$ & $\begin{array}{l}0.6 \\
1.0\end{array}$ & & $0 \cdot 4$ & $\begin{array}{l}0 \cdot 9 \\
1 \cdot 2\end{array}$ & & $\begin{array}{l}3.9 \\
0.5\end{array}$ & $20: 5-16: 0-D G$ & 26 \\
\hline
\end{tabular}

* Minor amounts of 18:0, 18:3 and 20:4 were present in some peaks.

HPLC and the positional distribution of fatty acids in each molecular species was determined. The lipid extraction, fractionation, purification and characterization procedure is summarized in Fig. 1.

\section{$M G D G$ fraction}

For this fraction, 10 species of lipids were successfully isolated by reverse-phase HPLC (Fig. 2). In contrast, the MGDG fractions from spinach leaves (Yamauchi et al., 1982) and the green alga Dunaliella salina (Lynch et al., 1983) contained five and six peaks, respectively. EPA (20:5) was one of the major fatty acids and was a significant component in every peak, except MG9 and MG10. DHA (22:6), another long-chain polyunsaturated fatty acid, was detected in two peaks in minor quantities. Peak MG2 was quantitatively the principal molecular species (Table 1). It contained EPA and 16:4 at approximately equimolar concentrations. The secondlargest peak was MG7, i.e. 20:5-16:1-MG (MG, mono- galactose). The concentration of galactose in all peaks matched well with the amounts of dominant fatty acids in each molecular species at the ratio of approximately $1: 2$. Therefore, the identification of this fraction as MGDG was confirmed.

Table 2 shows the positional distribution of fatty acid of each MGDG molecular species after hydrolysis by lipase from Rhizopus arrhizus. EPA was concentrated in the $s n-1$ position of this lipid fraction. On the other hand, $16: 4$ was found mainly at the $s n-2$ position. The results clearly identified the position of the fatty acids in all molecular species. The sequence of lipid elution followed the equivalent carbon number (ECN) theory (Christie, 1987) except for MG1 (20:5-16:0-MG).

In the MG4 peak, there appeared to be at least two fused peaks, as there were four major fatty acids, two in the $s n-1$ and two in the $s n-2$ position. Examination of the chromatogram showed that this peak was asymmetric. Based on ECN values, the two lipids were possibly a critical pair of 20:5-16:3-MG and 20:4-16:4-MG, which 
Table 5. Fatty acid distribution in the SQDG fraction

\begin{tabular}{lccccccr}
\hline \hline & \multicolumn{7}{c}{ Fatty acid content $(\mu \mathrm{mol})^{*}$} \\
\cline { 2 - 8 } Peak & $14: 0$ & $16: 0$ & $16: 1$ & $18: 0$ & $18: 1$ & $20: 5$ & $22: 6$ \\
\hline SQ1 & $\mathbf{1 0 8 . 5}$ & 0.7 & $\mathbf{9 3 . 6}$ & & 0.7 & 0.8 & 1.9 \\
SQ2 & $\mathbf{2 6 . 4}$ & 1.3 & 1.0 & 0.2 & & 0.5 & $\mathbf{1 9 . 1}$ \\
SQ3 & 2.7 & 7.3 & $\mathbf{6 0 . 6}$ & 0.8 & 1.0 & 3.0 & 0.9 \\
SQ4 & 8.3 & $\mathbf{1 3 0 . 1}$ & 2.9 & & 1.3 & $\mathbf{1 0 6 . 5}$ & 3.9 \\
SQ5 & 4.3 & 1.7 & 0.8 & 0.7 & $\mathbf{1 3 . 8}$ & 0.9 & $\mathbf{1 7 . 6}$ \\
SQ6 & $\mathbf{7 5 . 8}$ & $\mathbf{9 2 . 5}$ & 8.5 & & 0.4 & 1.0 & 0.9 \\
SQ7 & 3.4 & $\mathbf{1 8 8 . 0}$ & $\mathbf{1 6 6 . 9}$ & 0.7 & & 1.3 & \\
SQ8 & 1.3 & 1.0 & 0.4 & $\mathbf{1 . 5}$ & 0.6 & $\mathbf{1 . 7}$ & \\
SQ9 & 3.9 & $\mathbf{2 0 . 5}$ & 1.1 & & & 1.6 & \\
SQ10 & 4.3 & 1.2 & 0.7 & $\mathbf{3 . 0}$ & & & \\
\hline \hline
\end{tabular}

* Minor amounts of $18: 2,18: 3$ and 20:4 were present in some peaks.

had a tendency to elute together (El-Hamdy \& Perkins, 1981). Peak MG3 contained only one major identified fatty acid, EPA, and its concentration was much higher than and did not seem to match quantitatively the remaining identified fatty acids. However, there was another, unknown, fatty acid, the concentration of which was close to that of EPA. Its retention time was between those of $18: 3$ and $20: 4$, which indicated that this acid might be 18:4. Moreover, the calculated ECN value of this particular molecular species was 20 , while the previous peak was undoubtedly 20:5-16:4-MG with an ECN value of 18 . On this basis it was tentatively concluded that this fatty acid was $18: 4$.
In contrast to a marine red alga, Porphyra yezoensis, where EPA was the primary fatty acid at both the $s n-1$ and $s n-2$ positions of the glycerol moieties and 16:0 was the minor component at both positions of MGDG (Araki et al., 1987), Phaeodactylum tricornutum UTEX 640 contained EPA mainly at the $s n-1$ position, and a $\mathrm{C}_{16}$ fatty acid was at the $s n-2$ position.

\section{$D G D G$ fraction}

DGDG was separated into seven peaks by reverse-phase HPLC. The fatty acid distribution of most peaks was similar to that of MGDG, where EPA was the major fatty acid (Table 3). The largest DGDG peak was 20:516:1-DG (DG, digalactose). In most cases, galactose concentrations in each molecular species agreed with the combined molarity of the two fatty acids in the ratio of $1: 1$. In the DG3 peak, two lipid species appeared to elute together.

The number of isolated peaks was similar to that found in other phytoplankton (Araki et al., 1987; Lynch et al., 1983) and in plants (Yamauchi et al., 1982). Similarities in the fatty acid distribution of dominant DGDG species were also observed between this organism and Porphyra yezoensis (Araki et al., 1987).

Table 4 shows the positional distribution of fatty acids in each recovered peak after enzyme hydrolysis. Analysis of fatty acid position assisted in identifying the two unknown species present in the DG3 peak. The two

Table 6. Positional distribution of fatty acid in molecular species of lipid in the SQDG fraction

\begin{tabular}{|c|c|c|c|c|c|c|c|c|c|c|}
\hline \multirow[b]{2}{*}{ Peak } & \multirow[b]{2}{*}{ Posn } & \multicolumn{7}{|c|}{ Fatty acid content $(\mu \mathrm{mol})$} & \multirow{2}{*}{$\begin{array}{c}\text { Possible } \\
\text { SQDG }\end{array}$} & \multirow[b]{2}{*}{$\mathrm{ECN}$} \\
\hline & & $14: 0$ & $16: 0$ & $16: 1$ & $18: 0$ & $18: 1$ & $20: 5$ & $22: 6$ & & \\
\hline SQ1 & $\begin{array}{l}s n-1 \\
s n-2\end{array}$ & $\begin{array}{l}15.4 \\
56.2\end{array}$ & $\begin{array}{l}0.5 \\
0.5\end{array}$ & $\begin{array}{r}61.6 \\
2 \cdot 3\end{array}$ & 0.5 & $\begin{array}{l}0.3 \\
0.2\end{array}$ & $\begin{array}{l}0.3 \\
0.8\end{array}$ & $\begin{array}{l}0.7 \\
0.2\end{array}$ & $16: 1-14: 0-S Q$ & 28 \\
\hline SQ2 & $\begin{array}{l}s n-1 \\
s n-2\end{array}$ & $\begin{array}{r}1.5 \\
20.7\end{array}$ & $\begin{array}{l}0.7 \\
1.1\end{array}$ & $\begin{array}{l}2 \cdot 6 \\
0 \cdot 8\end{array}$ & & & $\begin{array}{l}0 \cdot 3 \\
0 \cdot 2\end{array}$ & $\begin{array}{r}15 \cdot 7 \\
0.5\end{array}$ & $22: 6-14: 0-S Q$ & 24 \\
\hline SQ3 & $\begin{array}{l}s n-1 \\
s n-2\end{array}$ & $\begin{array}{l}2.2 \\
0.7\end{array}$ & $\begin{array}{l}2 \cdot 3 \\
2 \cdot 8\end{array}$ & $\begin{array}{l}33.0 \\
26 \cdot 6\end{array}$ & $\begin{array}{l}0.3 \\
0.2\end{array}$ & & $\begin{array}{l}1.7 \\
0.6\end{array}$ & $\begin{array}{l}0.2 \\
0.3\end{array}$ & $16: 1-16: 1-S Q$ & 30 \\
\hline SQ4 & $\begin{array}{l}s n-1 \\
s n-2\end{array}$ & $\begin{array}{l}1.5 \\
0.7\end{array}$ & $\begin{array}{r}7.2 \\
101.4\end{array}$ & $\begin{array}{l}1 \cdot 4 \\
3 \cdot 0\end{array}$ & $0 \cdot 2$ & $\begin{array}{l}0.3 \\
1.4\end{array}$ & $\begin{array}{r}95.7 \\
3.7\end{array}$ & $\begin{array}{l}0.9 \\
0.5\end{array}$ & $20: 5-16: 0-S Q$ & 26 \\
\hline SQ5 & $\begin{array}{l}s n-1 \\
s n-2\end{array}$ & $\begin{array}{l}3 \cdot 5 \\
1 \cdot 8\end{array}$ & $\begin{array}{l}1 \cdot 3 \\
3 \cdot 3\end{array}$ & $\begin{array}{l}0.8 \\
0.3\end{array}$ & & $\begin{array}{r}0.9 \\
15.5\end{array}$ & $\begin{array}{l}1 \cdot 3 \\
0 \cdot 3\end{array}$ & $\begin{array}{r}14.6 \\
0.9\end{array}$ & $22: 6-18: 1-S Q$ & 26 \\
\hline SQ6 & $\begin{array}{l}s n-1 \\
s n-2\end{array}$ & $\begin{array}{r}67 \cdot 0 \\
5 \cdot 1\end{array}$ & $\begin{array}{r}3 \cdot 7 \\
76 \cdot 2\end{array}$ & $\begin{array}{l}2 \cdot 2 \\
1 \cdot 5\end{array}$ & 0.4 & $\begin{array}{l}1.0 \\
1.5\end{array}$ & $\begin{array}{l}0 \cdot 3 \\
0 \cdot 3\end{array}$ & 0.9 & $14: 0-16: 0-S Q$ & 30 \\
\hline SQ7 & $\begin{array}{l}s n-7 \\
s n-2\end{array}$ & $\begin{array}{l}3.7 \\
0.7\end{array}$ & $\begin{array}{r}7 \cdot 2 \\
142.0\end{array}$ & $\begin{array}{r}152.2 \\
8.9\end{array}$ & $\begin{array}{l}0.5 \\
0.3\end{array}$ & 0.4 & & & $16: 1-16: 0-S Q$ & 30 \\
\hline SQ8 & $\begin{array}{l}s n-1 \\
s n-2\end{array}$ & $\begin{array}{l}1 \cdot 1 \\
0 \cdot 9\end{array}$ & $\begin{array}{l}1 \cdot 2 \\
0 \cdot 2\end{array}$ & $\begin{array}{l}2.5 \\
0.9\end{array}$ & $4 \cdot 4$ & $\begin{array}{l}0.3 \\
0.2\end{array}$ & $0 \cdot 1$ & $\begin{array}{l}2.9 \\
0.4\end{array}$ & $20: 5-18: 0-S Q$ & 28 \\
\hline SQ9 & $\begin{array}{l}s n-1 \\
s n-2\end{array}$ & $\begin{array}{l}0.4 \\
0.7\end{array}$ & $\begin{array}{l}14 \cdot 1 \\
13 \cdot 6\end{array}$ & $\begin{array}{l}0.4 \\
0.7\end{array}$ & 0.2 & & & $\begin{array}{l}0 \cdot 3 \\
0 \cdot 2\end{array}$ & $16: 0-16: 0-S Q$ & 32 \\
\hline SQ10 & $\begin{array}{l}s n-1 \\
s n-2\end{array}$ & $\begin{array}{l}0.7 \\
6.9\end{array}$ & $\begin{array}{l}1.0 \\
0.7\end{array}$ & $\begin{array}{l}0.8 \\
0.6\end{array}$ & $\begin{array}{l}4 \cdot 1 \\
0.6\end{array}$ & $0 \cdot 1$ & & & $18: 0-14: 0-S Q$ & 32 \\
\hline
\end{tabular}


Table 7. Fatty acid distribution in the PC fraction

\begin{tabular}{|c|c|c|c|c|c|c|c|c|}
\hline \multirow[b]{2}{*}{ Peak } & \multicolumn{8}{|c|}{ Fatty acid content $(\mu \mathrm{mol})^{*}$} \\
\hline & $14: 0$ & $16: 0$ & $16: 1$ & $18: 1$ & $18: 2$ & $18: 3$ & $20: 5$ & $22: 6$ \\
\hline $\mathrm{PC1}$ & 0.9 & 2.5 & $3 \cdot 8$ & 0.5 & 0.4 & $1 \cdot 3$ & 9.2 & 6.7 \\
\hline $\mathrm{PC} 2$ & $1 \cdot 1$ & 0.7 & 0.6 & & 0.6 & 0.5 & $68 \cdot 1$ & 1.8 \\
\hline PC3 & 1.8 & 0.9 & 0.6 & $1 \cdot 3$ & 1.4 & 4.7 & $5 \cdot 2$ & 0.9 \\
\hline PC4 & 4.6 & 4.0 & 25.4 & 1.9 & 0.5 & 1.9 & 1.9 & $24 \cdot 4$ \\
\hline PC5 & 1.6 & $1 \cdot 1$ & 0.7 & 0.9 & 8.6 & & $6 \cdot 1$ & \\
\hline PC6 & $2 \cdot 6$ & 4.8 & 20.5 & $2 \cdot 4$ & $2 \cdot 3$ & & $20 \cdot 2$ & $1 \cdot 3$ \\
\hline PC7 & 11.9 & $2 \cdot 2$ & 10.2 & 0.6 & 0.9 & & 0.4 & \\
\hline PC8 & 1.6 & $7 \cdot 4$ & 1.2 & 1.5 & 8.9 & & 1.5 & \\
\hline PC9 & 25.8 & $35 \cdot 1$ & $2 \cdot 3$ & $2 \cdot 0$ & 0.8 & & 0.7 & \\
\hline PC10 & $3 \cdot 2$ & 1.9 & $16 \cdot 8$ & 13.8 & 0.5 & & 0.5 & \\
\hline PC11 & $5 \cdot 5$ & $46 \cdot 5$ & 2.6 & $2 \cdot 0$ & 1.6 & & & \\
\hline
\end{tabular}

* Minor amounts of 18:0 and 20:4 were present in some peaks.

lipids could be 20:5-18:2-X and 18:1-16:3-X. According to the ECN theory, these two species should have ECN values in the range of 20 to 24 (between DG2 and DG4). Therefore, 20:5-18:2-X, which had an ECN value of 24, was likely to contain digalactose moieties. On the other hand, the X moiety in the 18:1-16:3-X had an ECN value of 26 and could be another sugar or sugar derivative, as it was indicated previously that there was an overlap of a glycosylglycerolipid in the DGDG fraction during elution from the silica gel cartridge (Yongmanitchai \& Ward, 1992).

\section{$S Q D G$ fraction}

In this fraction, 10 lipid species were collected. The major fatty acids were 14:0, 16:0, 16:1 and 20:5 (Table 5). Four peaks, i.e. SQ1, SQ4, SQ6 and SQ7, were the principal lipids. In contrast to other lipid classes, where trace amounts of $\mathrm{C}_{14}$ acid were detected, the SQDG fraction contained a large quantity of $\mathrm{C}_{14}$ acid, particularly in peaks SQ1 and SQ6.

As in other cases, unsaturated fatty acids, including EPA, were usually located at the $s n-1$ position (Table 6). The sequence of elution of molecular species from the column did not follow the ECN theory exactly, and the separation of lipid species was not as clean as with the MGDG and DGDG fractions. This irregularity may have been due to the effect of sulphoquinovosyl moieties, which seemed to exhibit very high polarity.

\section{PC fraction}

Purification of the major phospholipid, PC, by normalphase HPLC yielded a major single lipid peak on the chromatogram. This phospholipid was separated by reverse-phase HPLC into 11 major peaks (Table 7). EPA was present in two predominant molecular species, PC2 and PC6. In contrast to other lipid classes, 22:6, which was usually present in small peaks, was one of the fatty

Table 8. Positional distribution of fatty acid in molecular species of lipid in the PC fraction

\begin{tabular}{|c|c|c|c|c|c|c|c|c|c|c|c|}
\hline \multirow[b]{2}{*}{ Peak } & \multirow[b]{2}{*}{ Posn } & \multicolumn{8}{|c|}{ Fatty acid content $(\mu \mathrm{mol})$} & \multirow{2}{*}{$\begin{array}{c}\text { Possible } \\
\text { PC }\end{array}$} & \multirow[b]{2}{*}{$\mathrm{ECN}$} \\
\hline & & $14: 0$ & $16: 0$ & $16: 1$ & $18: 1$ & $18: 2$ & $18: 3$ & $20: 5$ & $22: 6$ & & \\
\hline $\mathrm{PCl}$ & $\begin{array}{l}s n-1 \\
s n-2\end{array}$ & $\begin{array}{l}1 \cdot 2 \\
1 \cdot 1\end{array}$ & $\begin{array}{l}1 \cdot 1 \\
1 \cdot 4\end{array}$ & $\begin{array}{l}0.8 \\
0.8\end{array}$ & 0.6 & 0.9 & & $\begin{array}{l}6.2 \\
0.9\end{array}$ & $\begin{array}{l}1.8 \\
5.9\end{array}$ & $20: 5-22: 6-\mathrm{PC}$ & 20 \\
\hline PC2 & $\begin{array}{l}s n-1 \\
s n-2\end{array}$ & $\begin{array}{l}1.0 \\
1 \cdot 2\end{array}$ & $\begin{array}{l}0.6 \\
0.7\end{array}$ & $\begin{array}{l}0.4 \\
0.7\end{array}$ & & $\begin{array}{l}0.5 \\
0.5\end{array}$ & & $\begin{array}{l}31 \cdot 7 \\
29 \cdot 0\end{array}$ & $\begin{array}{l}0 \cdot 3 \\
0 \cdot 7\end{array}$ & $20: 5-20: 5-\mathrm{PC}$ & 20 \\
\hline PC3 & $\begin{array}{l}s n-1 \\
s n-2\end{array}$ & $\begin{array}{l}1 \cdot 4 \\
1.0\end{array}$ & $\begin{array}{l}0.8 \\
0.7\end{array}$ & $\begin{array}{l}0.9 \\
0.8\end{array}$ & $1 \cdot 0$ & 0.9 & $\begin{array}{l}0.5 \\
4 \cdot 2\end{array}$ & $\begin{array}{l}5 \cdot 8 \\
0.5\end{array}$ & & $20: 5-18: 3-\mathrm{PC}$ & 22 \\
\hline $\mathrm{PC} 4$ & $\begin{array}{l}s n-1 \\
s n-2\end{array}$ & $\begin{array}{l}1 \cdot 8 \\
2 \cdot 3\end{array}$ & $\begin{array}{l}1 \cdot 5 \\
2 \cdot 3\end{array}$ & $\begin{array}{r}3.8 \\
30.0\end{array}$ & & 0.5 & $\begin{array}{l}0.9 \\
0.5\end{array}$ & $\begin{array}{l}0 \cdot 8 \\
0 \cdot 6\end{array}$ & $\begin{array}{c}25 \cdot 6 \\
1 \cdot 1\end{array}$ & $22: 6-16: 1-\mathrm{PC}$ & 24 \\
\hline PC5 & $\begin{array}{l}s n-1 \\
s n-2\end{array}$ & $\begin{array}{l}0.9 \\
0.7\end{array}$ & $\begin{array}{l}0 \cdot 6 \\
1 \cdot 1\end{array}$ & $\begin{array}{l}1 \cdot 6 \\
1 \cdot 0\end{array}$ & 0.7 & $\begin{array}{l}0.9 \\
6.6\end{array}$ & & $\begin{array}{l}5.8 \\
0.6\end{array}$ & & $20: 5-18: 2-\mathrm{PC}$ & 24 \\
\hline PC6 & $\begin{array}{l}s n-1 \\
s n-2\end{array}$ & $\begin{array}{l}0 \cdot 7 \\
0 \cdot 7\end{array}$ & $\begin{array}{l}1 \cdot 4 \\
2 \cdot 6\end{array}$ & $\begin{array}{r}2.6 \\
19.9\end{array}$ & $\begin{array}{l}1.2 \\
0.7\end{array}$ & $\begin{array}{l}1.0 \\
0.5\end{array}$ & & $\begin{array}{r}22 \cdot 5 \\
1 \cdot 1\end{array}$ & & $20: 5-16: 1-P C$ & 24 \\
\hline PC7 & $\begin{array}{l}s n-1 \\
s n-2\end{array}$ & $\begin{array}{l}7 \cdot 3 \\
0 \cdot 7\end{array}$ & $\begin{array}{l}1 \cdot 3 \\
0.7\end{array}$ & $\begin{array}{l}0 \cdot 6 \\
8 \cdot 0\end{array}$ & & 0.5 & 0.7 & $\begin{array}{l}0.3 \\
0.5\end{array}$ & & $14: 0-16: 1-\mathrm{PC}$ & 28 \\
\hline PC8 & $\begin{array}{l}s n-1 \\
s n-2\end{array}$ & $\begin{array}{l}0.6 \\
0.7\end{array}$ & $\begin{array}{l}0.6 \\
9.9\end{array}$ & $\begin{array}{l}0.4 \\
0.8\end{array}$ & $\begin{array}{l}0 \cdot 7 \\
0.6\end{array}$ & $\begin{array}{l}7.6 \\
1.9\end{array}$ & & $0 \cdot 7$ & & $18: 2-16: 0-\mathrm{PC}$ & 30 \\
\hline PC9 & $\begin{array}{l}s n-1 \\
s n-2\end{array}$ & $\begin{array}{r}33 \cdot 3 \\
1 \cdot 4\end{array}$ & $\begin{array}{r}2 \cdot 6 \\
33 \cdot 7\end{array}$ & $\begin{array}{l}0.9 \\
0.8\end{array}$ & $1 \cdot 1$ & $0 \cdot 8$ & & $0 \cdot 6$ & & $14: 0-16: 0-\mathrm{PC}$ & 30 \\
\hline PC10 & $\begin{array}{l}s n-1 \\
s n-2\end{array}$ & $\begin{array}{l}1.0 \\
1.2\end{array}$ & $\begin{array}{l}1.9 \\
2 \cdot 1\end{array}$ & $\begin{array}{l}1 \cdot 3 \\
8 \cdot 5\end{array}$ & $\begin{array}{l}9.4 \\
1.0\end{array}$ & & & 0.6 & & $18: 1-16: 1-\mathrm{PC}$ & 30 \\
\hline PC11 & $\begin{array}{l}s n-1 \\
s n-2\end{array}$ & $\begin{array}{l}1 \cdot 8 \\
2 \cdot 0\end{array}$ & $\begin{array}{l}29.8 \\
22.7\end{array}$ & $\begin{array}{l}0.9 \\
0.7\end{array}$ & $0 \cdot 7$ & $0 \cdot 4$ & & & & $16: 0-16: 0-\mathrm{PC}$ & 32 \\
\hline
\end{tabular}


Table 9. Content of each molecular species in cell biomass

\begin{tabular}{|c|c|c|}
\hline Peak & $\begin{array}{l}\text { Proposed } \\
\text { structure }\end{array}$ & $\begin{array}{l}\text { Polar lipid content } \\
{\left[\mathrm{mg}(\mathrm{g} \text { cell dry } \mathrm{wt})^{-1}\right]^{*}}\end{array}$ \\
\hline MG1 & $20: 5-16: 0-M G$ & $3 \cdot 04$ \\
\hline MG2 & $20: 5-16: 4-M G$ & $41 \cdot 21$ \\
\hline MG3 & $20: 5-18: 4-\mathrm{MG}$ & 0.95 \\
\hline MG4 & $\begin{array}{c}20: 5-16 \cdot 3-M G \& \\
20: 5-16: 4-M G\end{array}$ & $8 \cdot 76$ \\
\hline MG5 & $20: 5-20: 5-\mathrm{MG}$ & 3.04 \\
\hline MG6 & $20: 5-16: 2-M G$ & $2 \cdot 38$ \\
\hline MG7 & $20: 5-16: 1-M G$ & $18 \cdot 05$ \\
\hline MG8 & $20: 5-18: 2-M G$ & 3.80 \\
\hline MG9 & $20: 4-16: 1-M G$ & $1 \cdot 48$ \\
\hline MG10 & $16: 1-16: 1-\mathrm{MG}$ & $6 \cdot 06$ \\
\hline DG1 & $20: 5-16: 4-\mathrm{DG}$ & $0 \cdot 70$ \\
\hline DG2 & $20: 5-16 \cdot 3-\mathrm{DG}$ & $6 \cdot 36$ \\
\hline DG3 & $\begin{array}{c}20: 5-18: 2-X \& \& \\
18: 1-16: 3-X\end{array}$ & $3 \cdot 55$ \\
\hline DG4 & $20: 5-16: 1-D G$ & 20.96 \\
\hline DG5 & $16: 1-16: 1-D G$ & 6.79 \\
\hline DG6 & $18: 1-16: 1-\mathrm{DG}$ & 1.48 \\
\hline DG7 & $20: 5-16: 0-D G$ & $5 \cdot 50$ \\
\hline SQ1 & $16: 1-14: 0-S Q$ & $10 \cdot 38$ \\
\hline SQ2 & $22: 6-14: 0-S Q$ & $2 \cdot 34$ \\
\hline SQ3 & $16: 1-16: 1-S Q$ & $3 \cdot 11$ \\
\hline SQ4 & $20: 5-16: 0-\mathrm{SQ}$ & $12 \cdot 14$ \\
\hline SQ5 & $22 \cdot 6: 18: 1-S Q$ & 1.61 \\
\hline SQ6 & $14: 0-16: 0-S Q$ & $8 \cdot 64$ \\
\hline SQ7 & $16: 1-16: 0-S Q$ & $18 \cdot 22$ \\
\hline SQ8 & $20: 5-18: 0-S Q$ & $0 \cdot 16$ \\
\hline SQ9 & $16: 0-16: 0-S Q$ & 1.06 \\
\hline SQ10 & $18: 0-14: 0-S Q$ & $0 \cdot 38$ \\
\hline $\mathrm{PC} 1$ & $20: 5-22: 6-\mathrm{PC}$ & $0 \cdot 48$ \\
\hline PC2 & $20: 5-20: 5-\mathrm{PC}$ & $2 \cdot 06$ \\
\hline PC3 & $20: 5-18: 3-P C$ & $0 \cdot 30$ \\
\hline PC4 & $20: 6-16: 1-P C$ & 1.65 \\
\hline PC5 & $20: 5-18: 2-\mathrm{PC}$ & $0 \cdot 45$ \\
\hline PC6 & $20: 5-16: 1-\mathrm{PC}$ & $1 \cdot 23$ \\
\hline PC7 & $14: 0-16: 1-\mathrm{PC}$ & 0.61 \\
\hline PC8 & $18: 2-16: 0-\mathrm{PC}$ & 0.50 \\
\hline PC9 & $14: 0-16: 0-P C$ & $2 \cdot 08$ \\
\hline PC10 & $18: 1-16: 1-P C$ & 0.92 \\
\hline $\mathrm{PC} 11$ & $16: 0-16: 0-\mathrm{PC}$ & 1.40 \\
\hline
\end{tabular}

* Calculated as total fatty acids.

acids in a principal species, PC4. PC6 gave an asymmetrical peak on the chromatogram, suggesting the possible presence of more than one lipid species. Hydrolysis by phospholipase $\mathrm{A}_{2}$ assisted in identifying the fatty acids in the $s n-1$ and $s n-2$ positions (Table 8 ). In many PC molecular species, polyunsaturated fatty acids, $18: 2,18: 3,20: 5$, and $22: 6$, tended to stay together, conferring on these lipids very high degrees of unsaturation.

\section{General remarks}

In general, the sequence of the elution of molecular species from HPLC columns, based on their ECN (Christie, 1987) agreed with and supported the con- clusion regarding lipid identities in the case of MGDG, DGDG and PC fractions. Notable exceptions were MG1 $(\mathrm{ECN}=26)$ and $\mathrm{DG} 7(\mathrm{ECN}=26)$. However, in the case of the SQDG fraction, there was little correlation between sequence of elution and ECN values.

The fatty acids located at the $s n-1$ position of lipid molecules are usually saturated fatty acids, while the $s n$ 2 position contains unsaturated fatty acids (Holub \& Kuksis, 1978; Klein \& Kemp, 1977). In contrast, EPA of $P$. tricornutum UTEX 640 was concentrated mainly at the $s n-1$ position, particularly in MGDG and DGDG, which was also the case for Porphyra yezoensis (Araki et al., 1987). In addition, the MGDG lipid of the Phaeodactylum tricornutum UTEX 640 contained a high concentration of $16: 4$ at the $s n-2$ position rather than $16: 3$ as was indicated in another strain of this organism (Arao et al., 1987). Arao et al. (1987) determined the distribution of fatty acids at the $s n-1$ and $s n-2$ positions of the MGDG, DGDG, SQDG and phospholipid fractions, but the individual molecular species present in each fraction were not separated.

In photosynthetic organisms, it is generally accepted that fatty acid moieties at the $s n-2$ position of acylglycerol lipids are synthesized either by the chloroplast (prokaryotic pathway) or by the endoplasmic reticulum (eukaryotic pathway) (Frentzen, 1986; Heemskeck \& Wintermans, 1987; Roughan \& Slack, 1982). The distribution of fatty acids at the $s n-2$ positions of acylglycerol lipids generally reflects their biosynthetic origin (Frentzen, 1986; Roughan \& Slack, 1982). Lipids in which the $s n-2$ position is occupied by $\mathrm{C}_{16}$ acids are of plastidic (prokaryotic) origin; those with $\mathrm{C}_{18}$ acids in that position are of cytoplasmic (eukaryotic) origin. For the eukaryotic pathway, in particular, PC plays a central role as the substrate of fatty acid desaturases (Demamdre $e t$ al., 1986; Murphy et al., 1985). If similar metabolic compartmentalization exists in algae, the molecular species of all three galactolipids, i.e. MGDG, DGDG and SQDG, in P. tricornutum UTEX 640 appear to be synthesized entirely in the chloroplast. Such a prokaryotic origin of galactolipids would agree with results for Chlamydomonas reinhardtii, a unicellular green alga (Giroud et al., 1988). Furthermore, $\mathrm{C}_{16}$ fatty acids were also located at the $s n-2$ position of many of the triglyceride and PC molecular species of $P$. tricornutum UTEX 640, suggesting the same chloroplast origin. In contrast, in the PC of Porphyra yezoensis, EPA occurred in both the $s n-1$ and $s n-2$ positions, whereas palmitic acid was confined to the $s n-1$ position (Araki et al., 1987). Some PC molecular species of $P$. tricornutum UTEX 640 possessed very high degrees of unsaturation. This was probably due to the function of this lipid at the biological membrane. In order to function properly, particularly at low temperature, membranes have to retain their fluidity 
(Harwood \& Russell, 1984). This characteristic relates directly to the fatty acid composition of the membranes, where PC is usually a major component.

The absolute amount of each molecular species present per gram dry weight of cells was also determined (Table 9). Of the 45 molecular species isolated, EPA was present in 20 of the proposed structures, but predominantly in the MGDG and DGDG classes, where it was present in 13 of the 17 proposed structures. Only two of the ten SQDG proposed structures contained EPA.

Support for this research by the Natural Sciences and Engineering Research Council of Canada is gratefully acknowledged.

\section{References}

Araki, S., Sakurai, T., Kawaguchi, A. \& Murata, N. (1987). Positional distribution of fatty acids in glycerolipids of the marine red alga, Porphyra yezoensis. Plant Cell Physiology 28, 761-766.

Arao, T., Kawaguchi, A. \& Yamada, M. (1987). Positional distribution of fatty acids in lipids of the marine diatom Phaeodactylum tricornutum. Phytochemistry 26, 2573-2576.

BLIGH, E. G. \& DYER, W. J. (1959). Rapid method of total lipid extraction and purification. Canadian Journal of Biochemistry and Physiology 37, 911-917.

Christie, W. W. (1987). HPLC and Lipids - a Practical Guide, p. 272. Oxford: Pergamon Press.

ChristiE, W. W. (1988). Equivalent chain-lengths of methyl ester derivatives of fatty acids on gas chromatography. Journal of Chromatography 447, 305-314.

Demamdre, C., Tremolieres, A., Justin, A.-M. \& Mazliak, P. (1986). Oleate desaturation in six phosphatidylcholine molecular species from potato tuber microsomes. Biochimica et Biophysica Acta 877, 380-386.

Dyerberg, J., Bank, H. O., Stoffersen, E., Moncada, S. \& Vane, J. R. (1978). Eicosapentaenoic acid and prevention of thrombosis and atherosclerosis. Lancet ii, 117-119.

El-Hamdy, A. H. \& PeRkins, E. G. (1981). High performance reversed phase chromatography of natural triglyceride mixtures: critical pair separation. Journal of the American Oil Chemists' Society 58, 867-872.

Fischer, W., Heinz, E. \& Zeus, M. (1973). The suitability of lipase from Rhizopus arrhizus delemar for analysis of fatty acid distribution in dihexosyl diglycerides, phospholipids and plant sulfolipids. HoppeSeyler's Zeitschrift für physiologische Chemie 354, 1115-1123.

FrentZen, M. (1986). Biosynthesis and desaturation of different diacylglycerol moieties in higher plants. Journal of Plant Physiology 124, 193-209.
Giroud, C., Gerber, A. \& Eichenberger, W. (1988). Lipids of Chlamydomonas reinhardtii. Analysis of molecular species and intracellular site(s) of biosynthesis. Plant Cell Physiology 29, $587-595$.

HARwOOD, J. L. \& Russell, N. J. (1984). Lipids in Plants and Microbes, p. 162. London: George Allen \& Unwin.

HeEmskeck, J. W. M. \& Wintermans, J. F. G. M. (1987). Preliminary observations on the nutritional value of 'Tahiti Isochrysis' to bivalve larvae. Aquaculture 62, 281-288.

HoluB, B. J. \& KuKsIS, A. (1978). Metabolism of molecular species of diacylglycerophospholipids. Advances in Lipid Research 15, 1-125.

HoluB, B. J. \& SKEAFF, C. M. (1987). Nutritional regulation of cellular phosphatidylinositol. Methods in Enzymology 141, 234-244.

Kaitaranta, J. K. \& Bessman, S. P. (1981). Determination of phospholipids by a combined liquid chromatograph-automated phosphorus analyzer. Analytical Chemistry 53, 1232-1235.

KLEIN, R. A. \& KEMP, P. (1977). Recent methods for elucidation of lipid structures. Methods in Membrane Biology 8, 51-217.

LyNCh, D. V., Gundersen, R. E. \& Thompson, G. A. (1983). Separation of galactolipid molecular species by high-performance liquid chromatography. Plant Physiology 72, 903-905.

Miwa, T. K., Midolajczak, K. L., Earle, F. R. \& Wolff, I. A. (1960). Gas chromatographic characterization of fatty acid identification constants for mono- and dicarboxylic methyl esters. Analytical Chemistry 32, 1739-1742.

Murphy, D. J., Woodrow, I. E. \& MukherJeE, K. D. (1985). Substrate specificities of the enzymes of the oleate desaturase system from photosynthetic tissue. Biochemical Journal 225, 267-270.

Roughan, P. G. \& SlaCK, C. R. (1982). Cellular organization of glycerolipid metabolism Annual Review of Plant Physiology 33, $97-132$.

Simopoulos, A. P. (1989). Summary of the NATO advanced research workshop on dietary $\omega-3$ and $\omega-6$ fatty acids: biological effects and nutritional essentiality. Journal of Nutrition 119, 521-528.

Watanabe, T., Fukushima, H. \& Nozawa, Y. (1980). Positional distribution of fatty acid in diacyl- and akyl-acylphosphatidylcholines and -(2-aminoethyl)phosphonolipids from cells grown at different temperatures. Biochimica et Biophysica Acta 620, 133-141.

Yamauchi, R., Kojima, M., Isogai, M., Kato, K. \& Ueno, Y. (1982). Separation and purification of molecular species of galactolipids by high performance liquid chromatography. Agricultural and Biological Chemistry 46, 2847-2849.

YongmanitchaI, W. \& WARD, O. P. (1991a). Growth and omega-3 fatty acid production by Phaeodactylum tricornutum under different culture conditions. Applied and Environmental Microbiology 57, 419-425.

YongmanitchaI, W. \& WaRD, O.P. (1991b). Screening of algae as potential alternative sources of eicosapentaenoic acid. Phytochemistry 30, 2963-2967.

YongmanitchaI, W. \& WARD, O. P. (1992). Separation of lipid classes from Phaeodactylum tricornutum using silica cartridges. Phytochemistry 31, 3405-3409. 